\title{
Green Synthesis, Characterization and Antibacterial Activity of Silver Nanoparticles of Endophytic Fungi Aspergillus terreus
}

Reena Rani, Dushyant Sharma, Monika Chaturvedi and J P Yadav*

Department of Genetics, M. D. University, Rohtak, 124001, Haryana, India

\begin{abstract}
In present study, the silver nanoparticles were synthesized using endophytic fungi Aspergillus terreus, isolated from Calotropis procera. Synthesized nanoparticles were characterized using various spectroscopic techniques. The nanoparticles were reported oval to spherical in shape. The average size of silver nanoparticles was $16.54 \mathrm{~nm}$. Gas chromatography-mass spectrometry analysis of Aspergillus terreus showed the presence of 17 compounds. The synthesized silver nanoparticles showed considerable antibacterial activity against tested bacterial strains: 9 American type culture collection reference (ATCC) and 3 multidrug resistance (MDR) strains. Synthesized nanoparticles showed significant antibacterial activity against Salmonella typhi $(16.67 \pm 0.58 \mathrm{~mm})$, Staphylococcus aureus $(15.67 \pm 0.58$ $\mathrm{mm})$, and Escherichia coli $(15.67 \pm 0.58 \mathrm{~mm})$. Minimum inhibitory concentration was reported in range of $11.43 \mu \mathrm{g} / \mathrm{ml}$ to $308 \mu \mathrm{g} / \mathrm{ml}$. Cell leakage analysis reported an increase in protein leakage level and degradation of nucleic acid after treatment with silver nanoparticles. The present study concluded that endophytic fungi Aspergillus terreus isolated from Calotropis procera can be used as a source for synthesis of silver nanoparticles and suggesting as an effective antibacterial agent.
\end{abstract}

Keywords: Aspergillus terreus; Antibacterial activity; Gas chromatography-mass spectrometry (GC-MS); Multidrug resistance (MDR); Silver nanoparticles; Protein leakage analysis

\section{Introduction}

Plants in nature accommodate diverse group of symbiotic and nonsymbiotic microorganisms and these microbes play significant role in plant development, growth, and protection. This association of plant and microbes is significant for their survival in stressed environment [1]. Endophytic fungi are among the organisms, which are in symbiotic association with plants, along with bacteria and yeast.

Due to development and dissemination of antibiotic resistance genes, it is difficult or impossible to treat bacterial infections. At present time development of multidrug resistance (MDR) in bacterial strains is one of the most alarming threats. Rapid development of drug resistance among bacteria threatens the extraordinary health benefits that have been achieved after discovery of first antibiotic "Penicillin". As bacteria have intrinsic ability to develop drug resistance there is continuous need of development of new antibiotics or materials, alternative treatment therapies and novel treatment approaches that can cope with this serious issue [2]. Non-traditional antibacterial agents are thus grabbing more attentions and offers great opportunities to overcome resistance. Biosynthesized silver nanoparticles (AgNPs) emerge as viable alternative for treatment of bacterial infections.

Over last few decades, nanotechnology rapidly emerges as an important field of science dealing with synthesis and manipulation of particle structure on nanoscale $(1-100 \mathrm{~nm})$. Due to very small size, nanoparticles acquire new physiochemical properties like catalytic activity, electric and thermal conductivity etc. as compared to their bulk. These physiochemical properties of nanoparticles are responsible for rapidly increase in their application in various fields like medical, textile, drug delivery, catalysis, environmental remediation, biological labeling, electronics, mechanics, chemical industries, and optics $[3,4]$. Nanoparticles can be synthesized using various methods: physical, chemical, and biological. Physical and chemical methods include synthesis by evaporation-condensation, laser ablation, microwave, chemical reduction, vapours deposition, sol-gel process, laser pyrolysis etc. Biological methods include synthesis using extracts from plants, fungi, algae, bacteria, and agricultural waste. Biological synthesis approach offers various advantages over other physical and chemical methods in terms of rapid synthesis, cost, eco-friendly, and less toxicity. Synthesis of metallic nanoparticles by using biological materials is a bio-redox reaction mainly carried out by secondary metabolites, cellular enzymes, and other cellular constituents. The biological materials for synthesis of nanoparticles include algae, fungi, yeast, bacteria, actinomycetes and plants. Though chemical method of silver nanoparticles resulted in a high yield as comparative to biological method but this technique is not suitable due to involvement of hazardous chemicals and high cost of production. Various factors like $\mathrm{pH}$, temperature, incubation time, and method of synthesis, types of biological material and their cellular content influenced the size, shape and activity of synthesized silver nanoparticles [5]. Among various noble metals, silver is most commonly used for the synthesis of nanoparticles due to its stability, electrical conductivity, catalytic activity, and surface plasmon resonance (SPR) [6].

As endophytic fungi possess large diversity but there is a limited number of reports on synthesis of AgNPs using endophytic fungi extracts are available. They provide several advantages over the bacteria, i.e. easy handling, simple nutrient requirement, secretion of large amount of extracellular protein being eukaryote, possess metal intake and tolerance capability [7,8]. Despite these facts, during extracellular biosynthesis of nanoparticles using fungi, they offer easier downstream processing than bacteria [9]. Therefore, in the present

*Corresponding author: Jaya Parkash Yadav, Department of Genetics, M.D. University, Rohtak-124001, Haryana, India, Tel: 9109416474640; E-mail: yadav1964@rediffmail.com

Received: August 17, 2017; Accepted: August 24, 2017; Published: August 31 2017

Citation: Rani R, Sharma D, Chaturvedi M, J P Yadav (2017) Green Synthesis, Characterization and Antibacterial Activity of Silver Nanoparticles of Endophytic Fungi Aspergillus terreus. J Nanomed Nanotechnol 8: 457. doi: 10.4172/21577439.1000457

Copyright: (c) 2017 Rani R, et al. This is an open-access article distributed under the terms of the Creative Commons Attribution License, which permits unrestricted use, distribution, and reproduction in any medium, provided the original author and source are credited. 
Citation: Rani R, Sharma D, Chaturvedi M, J P Yadav (2017) Green Synthesis, Characterization and Antibacterial Activity of Silver Nanoparticles of Endophytic Fungi Aspergillus terreus. J Nanomed Nanotechnol 8: 457. doi: 10.4172/2157-7439.1000457

Page 2 of 8

study, our attempt was to synthesized extracellular AgNPs using Aspergillus terreus (A. terreus) isolated from healthy Calotropis procera (C. procera). The synthesized nanoparticles were further subjected for their characterization and antibacterial efficacy against MDR and reference bacterial strains.

\section{Materials and Methods}

\section{Isolation and identification of endophytic fungi}

Healthy tissues (leaf, stem, and root) of C. procera plant were collected from M. D. University, Rohtak, Haryana, India. Plant identification was confirmed by voucher number MDU 4602. Sterilization of tissues was carried out using Schulz et al. [10] procedure. Plant tissues were washed thoroughly under running tap water and were surface sterilized, first immersed in $70 \%$ ethanol for $60 \mathrm{sec}$, followed by sodium hypochloride ( $4 \%$ of available chlorine) for $3 \mathrm{~min}$ and then dipped in $75 \%$ of ethanol for $30 \mathrm{sec}$. Finally, sterilized samples were rinsed with autoclaved distilled water thrice and allowed to dry in laminar air flow. The plant samples were cut into small pieces (of approximately of same size) and placed on the Petri plates containing potato dextrose agar (PDA, Himedia Pvt. Ltd. India) complemented with streptomycin $(100 \mathrm{mg} / \mathrm{L}$, Himedia Pvt. Ltd. India) to prevent endophytic bacterial growth. Petri plates were incubated at $28 \pm 2^{\circ} \mathrm{C}$, observed on regular basis for endophytic fungal growth. Pure culture of endophytic fungi was obtained after continuous transfer of hyphal tips on fresh PDA plates. Identification of isolated fungi was carried by PCR using ITS1 and ITS4 primer pair. All isolated endophytic fungi screened for antibacterial activity and A. terreus showed significant activity against tested bacterial strains. Hence, it was further selected for synthesis of AgNPs.

\section{Extracellular synthesis of silver nanoparticles}

A. terreus was inoculated in Potato Dextrose Broth (PDB) and incubated at $28 \pm 2^{\circ} \mathrm{C}$ on an incubator shaker with $150 \mathrm{rpm}$ for 6 days. Fungal biomass was filtered using Whatman filter paper no.1 and washed repeatedly with distilled water to remove the media. $20 \mathrm{~g}$ of fungal biomass taken into a flask of $500 \mathrm{ml}$ containing $100 \mathrm{ml}$ of distilled water and boiled for 15-20 min. Biomass was filtered using Whatman filter paper no. 1 and filtrate was used further for synthesis of AgNPs. 20 $\mathrm{ml}$ of fungal extract was mixed with aqueous solution of silver nitrate $(80 \mathrm{ml} ; 2 \mathrm{mM})$. Mixture was incubated at room temperature.

\section{Phytochemical analysis using GC-MS}

GC-MS analysis of A. terreus was carried out using GC-MS analyzer (BRUKER SCION 436-GC SQ, USA). The column used was Rtx ${ }^{8}-5$ of $30 \mathrm{~m}$ length, $0.25 \mathrm{~mm}$ column inside diameter with $0.25 \mu \mathrm{m}$ film coating. Sample was filtered through Whatman ${ }^{\text {rax }}$ FILTER DEVICE $(0.2$ $\mu \mathrm{m})$. Helium (99.999\%) gas was used as carrier with a flow rate of $1 \mathrm{ml} /$ min in split mode. A volume of $1 \mu \mathrm{L}$ of fungal extract was injected to column with $280^{\circ} \mathrm{C}$ inlet temperature. The temperature of oven initially set at $70^{\circ} \mathrm{C}$ for $2 \mathrm{~min}$ and then it was elevated at rate of $7^{\circ} \mathrm{C} / \mathrm{min}$ up to $320^{\circ} \mathrm{C}$. Temperature of the ion sources was maintained at $250^{\circ} \mathrm{C}$. The mass spectrum of compounds present in fungal extract was obtained by electron ionization at $70 \mathrm{eV}$ and detector operates in scan mode 30 to $500 \mathrm{Da}$ atomic units. Total running time was $22.5 \mathrm{~min}$ including $3 \mathrm{~min}$ solvent delay. The obtained spectrum of the extract was compared with the database of National Institute of Science and Technology (NIST) library.

\section{Characterization of synthesized nanoparticles}

Four different techniques were used for characterization of synthesized AgNPs. Initial characterization was performed by UV-Vis spectroscopy using Shimadzu UV-2450 spectrophotometer, Japan. Wavelength range for absorption was $300-525 \mathrm{~nm}$ and distilled water was used as blank. Reaction mixture was centrifuged to concentrate synthesized AgNPs at $12000 \mathrm{rpm}$ for $15 \mathrm{~min}$. Finally, unbounded capping material was removed by repeating washing (4 times) with double distilled water. Thereafter, the obtained pellet was lyophilized to obtain synthesized AgNPs in powdered form. Fourier Transform Infra-red Spectroscopic analysis (FTIR) was used for detection of different functional groups involved in stabilization and capping of synthesized nanoparticles. Dried powder form of nanoparticles was analyzed using Alpha FTIR-ATR (Bruker, Germany). Characteristic peaks were recorded in between $400-4000 \mathrm{~cm}^{-1}$ at resolution $4 \mathrm{~cm}^{-1}$. Analysis was performed twice for the confirmation of transmittance spectra. The surface morphology of synthesized nanoparticles was studied using Scanning Electron Microscopy (SEM) technique. Lyophilized AgNPs were coated on stabs and images were obtained scanning electron microscope EVO18 Zeiss (CARL ZEISS, Germany) at $20 \mathrm{kV}$ voltage. The shape and size of mycosynthesized AgNPs were determined by transmission electron microscopy (TEM) analysis. Firstly, lyophilized AgNPs were suspended in methanol. A drop of suspended nanoparticles put on copper grid and allowed to dry at room temperature. Images were obtained with Tecnai, G 20 (FEI) at $200 \mathrm{KV}$ with different magnification. SEM and TEM analysis were carried by availing facility of SAIF at AIIMS, New Delhi.

\section{Antibacterial activity}

Tested bacterial strains: Antibacterial activity of AgNPs synthesized from $A$. terreus extract was screened against total 12 bacterial strains; 9 reference (Pseudomonas aeruginosa ATCC 27853, Serratia marcescens ATCC 27137, Shigella flexneri ATCC 12022, Salmonella typhi ATCC 13311, Escherichia coli ATCC 25922, Proteus mirabilis ATCC 43071, Klebsiella pneumoniae ATCC 700603, Enterococcus faecalis ATCC 29212, and Staphylococcus aureus ATCC 259323) and 3 multidrug resistance (MDR) strains (Escherichia coli MDREC1, Klebsiella pneumoniae MDRKP2, and Pseudomonas aeruginosa MDRPA3). MDR strains were obtained from the PGIMS (Microbiology Department), Rohtak, Haryana, India.

Agar well diffusion assay: Antibacterial activity of AgNPs was determined using agar well diffusion assay [11]. 24 hour old inoculated bacteria $(100 \mu \mathrm{L})$ were uniformly spread on nutrient agar Petri plates. Wells of $6 \mathrm{~mm}$ were made with the help of sterile borer. Stock solutions of nanoparticles at different concentrations $(10 \mathrm{mg} / \mathrm{ml}, 20 \mathrm{mg} / \mathrm{ml}, 30$ $\mathrm{mg} / \mathrm{ml}$, and $40 \mathrm{mg} / \mathrm{ml}$ ) were prepared in dimethyl sulphoxide (DMSO, $1 / 10^{\text {th }}$ diluted). $20 \mu \mathrm{l}$ of each concentration was added to well for all bacterial strains tested. Streptomicin (HiMedia laboratories Pvt. Ltd. India, $10 \mu \mathrm{g} / \mathrm{disc}$ ) was used as standard, while same volume of fungal filterate and silver nitrate used as control. Zone of inhibition of nanoparticles was measured with the help of a standard transparent scale HiAntibiotic ZoneScaleTM ${ }^{\mathrm{C}}$ (HiMedia Laboratories Pvt. Ltd., India).

Minimum inhibitory concentration (MIC): Minimum inhibitory concentration (MIC) is the lowest concentration of an antibacterial agent to inhibit the growth of bacterial growth. MIC values for synthesized AgNPs were determined using micro broth dilution method of Sarker et al. [12]. A volume of $50 \mu$ of each sterile nutrient broth and normal saline was added to each well of microtitre plate. $50 \mu \mathrm{l}$ of nanoparticle solution dissolved in DMSO $(25 \mathrm{mg} / \mathrm{ml})$ was added to the first row of the microtitre plate followed by serial dilution across. $10 \mu \mathrm{l}$ of each resazurin (indicator) and bacterial inoculums 
Citation: Rani R, Sharma D, Chaturvedi M, J P Yadav (2017) Green Synthesis, Characterization and Antibacterial Activity of Silver Nanoparticles of Endophytic Fungi Aspergillus terreus. J Nanomed Nanotechnol 8: 457. doi: 10.4172/2157-7439.1000457

Page 3 of 8

(approximately $1.5 \times 10^{8} \mathrm{CFU} / \mathrm{ml}$ ) were added to each well. Plates were wrapped in cling film to prevent dehydration of bacteria and incubated at $37^{\circ} \mathrm{C}$ for $24 \mathrm{~h}$. Experiments were performed in triplicate to avoid any error. Change of color from purple to pink or colorless indicated the growth of bacteria. The lowest concentration at which no color change observed was considered as the MIC value AgNPs.

\section{Cell leakage analysis}

Protein leakage analysis: Bacterial cultures were treated with $\operatorname{AgNPs}(10 \mathrm{mg} / \mathrm{ml})$ and incubated at $35 \pm 2^{\circ} \mathrm{C}$ for $8 \mathrm{~h}$. After incubation bacterial culture were centrifuged at $4^{\circ} \mathrm{C}(6000 \mathrm{rpm}, 5 \mathrm{~min})$ and supernatant were collected. Bradford [13] method was used to determine the intracellular protein leakage in treated and control bacterial supernatant The assay mixture consists of $150 \mu \mathrm{l}$ of supernatant and $150 \mu \mathrm{l}$ of Bradford reagent, incubated at room temperature in dark and absorbance was measured at $595 \mathrm{~nm}$ using ELISA reader. Bovine serum albumin (BSA) was used as standard. Agarose gel electrophoresis was performed for treated and control supernatant to determine the nucleic acid leakage.

\section{Results}

\section{Phytochemical analysis using GC-MS}

GC-MS analysis of $A$. terreus extract indicated the presence of 17 compounds when compared with NIST database (Table 1 and Figure 1). The major compounds identified were (E)-9-octadecenoic acid ethyl ester (21.952\%), hexadecanoic acid (16.591\%), ethyl ester (16.591\%), oleic Acid (11.382\%), dodecanoic acid (8.488\%), eicosanoic acid, ethyl ester (7.264\%), and docosanoic anhydride (7.177\%).

\section{Characterization of synthesized silver nanoparticles}

UV-Vis spectrophotometric technique is one of the most

\begin{tabular}{|c|c|c|c|c|c|}
\hline S. No. & RT & Name of compounds & $\%$ area & Common name & Class of compound \\
\hline 1 & 7.956 & Dodecanoic acid & 8.488 & Capric acid & Saturated fatty acid \\
\hline 2 & 8.11 & Dodecanoic acid, ethyl ester & 4.31 & Lauric acid, ethyl ester & Lipids \\
\hline 3 & 9.556 & Tetradecanoic acid, ethyl ester & 3.259 & Ethyl myristate & Fatty acid \\
\hline 4 & 10.232 & Eicosanoic acid, 2-ethyl-2-methyl-, methyl ester & 1.59 & Arachidic acid, esters & Lipids \\
\hline 5 & 10.74 & Ethyl 9-hexadecenoate & 2.716 & Palmitelaidic acid ethyl ester & Fatty acid esters \\
\hline 6 & 10.879 & Hexadecanoic acid, ethyl ester & 16.591 & Palmitic acid & Fatty acid \\
\hline 7 & 11.51 & Docosanoic anhydride & 2.445 & Behenic anhydride & Carboxylic acid \\
\hline 8 & 11.802 & Gamolenic Acid & 3.373 & Gamma linoleic acid & Fatty acid \\
\hline 9 & 11.925 & (E)-9-Octadecenoic acid ethyl ester & 21.952 & Oleic acid ethyl ester & Fatty acid \\
\hline 10 & 12.079 & Eicosanoic acid, ethyl ester & 7.264 & Eicosanoic acid, ethyl ester & Carboxylic acid \\
\hline 11 & 12.679 & Docosanoic anhydride & 7.177 & Behenic anhydride & Carboxylic acid \\
\hline 12 & 13.172 & Di(2-ethylhexyl)adipate & 1.185 & Diethylhexyl adipate & Ester \\
\hline 13 & 13.541 & Gamolenic Acid & 1.656 & Gamma linoleic acid & Fatty acid \\
\hline 14 & 13.679 & Oleic Acid & 11.382 & Oleic acid & Fatty acid \\
\hline 15 & 13.817 & Docosanoic anhydride & 3.458 & Behenic acid anhydride & Carboxylic acid \\
\hline 16 & 16.171 & 10-Bromodecanoic acid, ethyl ester & 1.395 & 10-Bromodecanoic acid, ethyl ester & Carboxylic acid \\
\hline 17 & 16.309 & Squalene & 1.759 & Squalene & Steroids \\
\hline
\end{tabular}

Table 1: GC-MS analysis of ethyl acetate extract of endophytic fungi $A$. terreus.

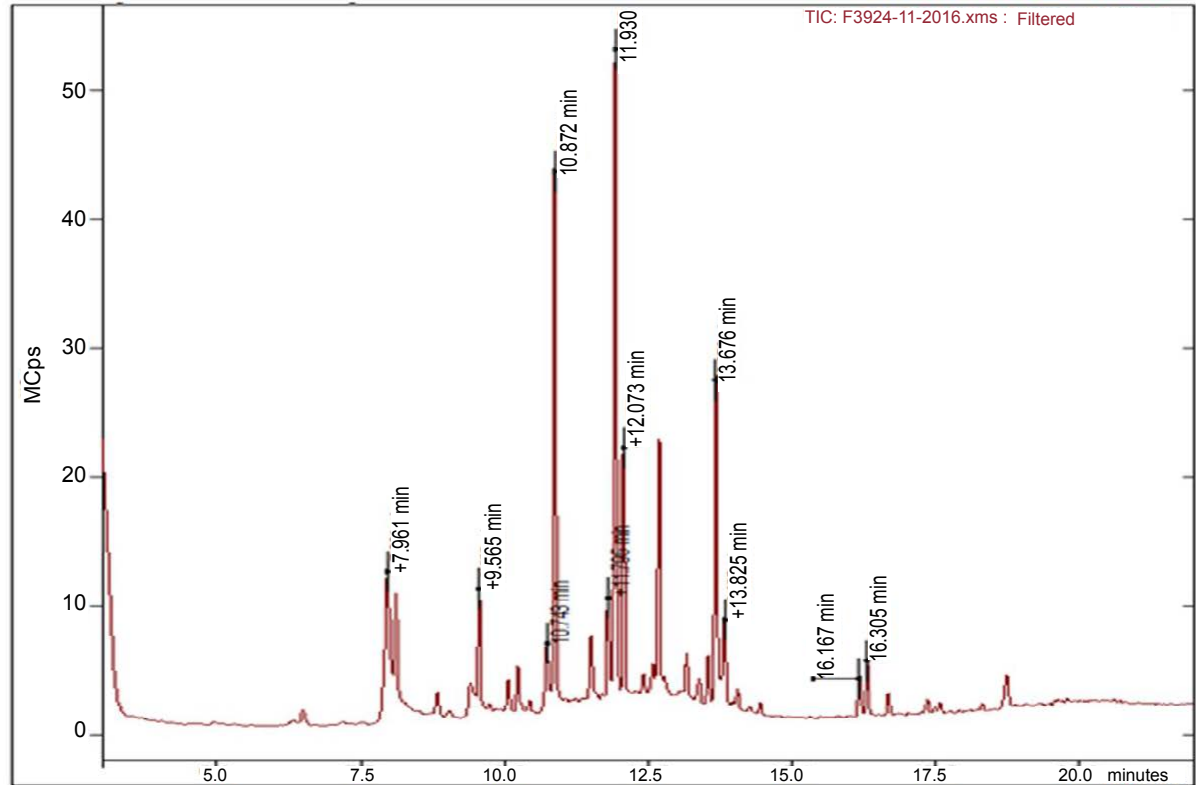

Figure 1: GC-MS spectrum of $A$. terreus. 
Citation: Rani R, Sharma D, Chaturvedi M, J P Yadav (2017) Green Synthesis, Characterization and Antibacterial Activity of Silver Nanoparticles of Endophytic Fungi Aspergillus terreus. J Nanomed Nanotechnol 8: 457. doi: 10.4172/2157-7439.1000457

commonly used techniques for initial characterization of synthesized nanoparticles. Change in color was observed from pale yellow to grayish after addition of aqueous extract of endophytic fungi to $2 \mathrm{mM}$ silver nitrate solution. This change in color is due to SPR phenomenon exhibited by metal nanoparticles in the aqueous solution. A strong peak specific for the production of AgNPs was observed at 410-425 $\mathrm{nm}$ as shown in Figure 2 [14]. FTIR analysis was generally carried out to identify the functional group involved in reduction of silver ion to metallic AgNPs. The observed spectrum is represented in Figure 3. Peaks at different wavelength correspond to different functional groups. FTIR spectra showed peaks at 529,558, and $593 \mathrm{~cm}^{-1}$ represented C-Br stretching suggesting the presence of alkyl halides. Peaks at 628,667 and $697 \mathrm{~cm}^{-1}$ were related to $\mathrm{C}-\mathrm{Cl}$ stretching, suggested the presence of halogens. The bands at 930 and $951 \mathrm{~cm}^{-1}$ correspond to $=\mathrm{C}-\mathrm{H}$ bending; they may be confined for presence of alkenes. Peaks at 1406 and 1436 $\mathrm{cm}^{-1}$ showed the $\mathrm{O}-\mathrm{H}$ bending could be attributed to the presence of carboxylic acids. Peak at $1995 \mathrm{~cm}^{-1}$ suggested the $\mathrm{N}=\mathrm{C}=\mathrm{S}$ stretching

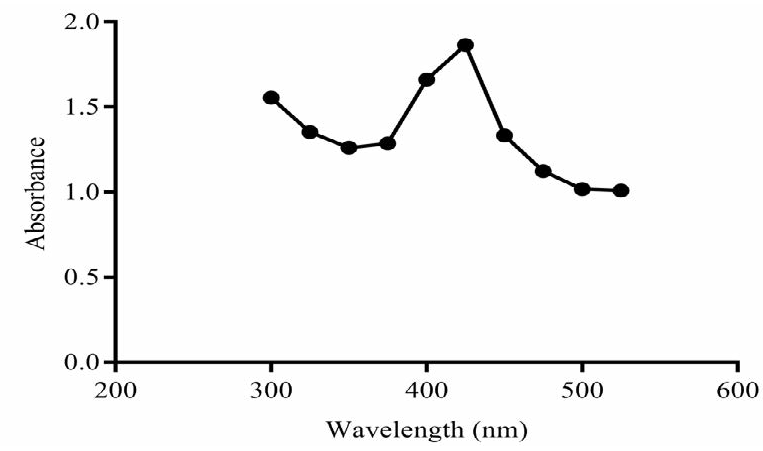

Figure 2: Representing UV-Vis absorption spectra of synthesized silver nanoparticles using $A$. terreus at range of $300-525 \mathrm{~nm}$. may corresponds to peresence of isothiocynate. Peaks at 2818, 2912 and $2996 \mathrm{~cm}^{-1}$ regions arising from C-H stretching of alkanes compounds were observed. The band at $3385 \mathrm{~cm}^{-1}$ corresponds to $\mathrm{O}-\mathrm{H}$ bending which suggested the presence of phenols.

SEM analysis of AgNPs showed almost spherical structure (Figure 4). Nanoparticles were dispersed; no aggregates indicated stabilization of the synthesized AgNPs [15]. TEM analysis provides detail information about size and surface morphology. TEM analysis of AgNPs predominated with spherical and oval particles represented an average size of $16.45 \mathrm{~nm}$ (Figure 5)

\section{Antibacterial activity}

Antibacterial activity of synthesized AgNPs was tested at various concentrations i.e. $10 \mathrm{mg} / \mathrm{ml}, 20 \mathrm{mg} / \mathrm{ml}, 30 \mathrm{mg} / \mathrm{ml}$, and $40 \mathrm{mg} / \mathrm{ml}$ using agar well diffusion method. The zone of inhibition for reference bacterial strains was ranging from $13.67 \pm 0.58$ to $16.67 \pm 0.58 \mathrm{~mm}$ (Table 2). Antibacterial activity is directly related with concentration of AgNPs, as it increases with increase in concentration. It was observed that mycosynthesized AgNPs exhibited considerable antibacterial activity with reference as to controls (fungal filterate and silver nitrate). $S$. typhi strain was found to be most susceptible as showed highest zone of inhibition ( $16.67 \pm 0.58 \mathrm{~mm}$ ), followed by E. coli, and $S$. aureus $(15.67 \pm 0.58 \mathrm{~mm}), S$. marcescens $(15.33 \pm 0.58 \mathrm{~mm})$. Lowest zone of inhibition was reported for K. pneumoniae (MDR) $(13.33 \pm 0.58 \mathrm{~mm})$, and $K$. pneumoniae ATCC strain was reported to be least susceptible as showed minimum zone of inhibition among all tested reference strains $(13.67 \pm 0.58 \mathrm{~mm})$. The MIC of synthesized AgNPs from A. terreus against different reference bacterial strains was $11.43-308 \mu \mathrm{g} / \mathrm{ml}$. ATCC strains S. typhi, E. coli, S. aureus, S. flexneri, and S. marcescens showed the MIC values of $11.43 \mu \mathrm{g} / \mathrm{ml}$. MIC values observed for $P$. aeruginosa was $32.2 \mu \mathrm{g} / \mathrm{ml}$, for P. mirabilis and E. faecalis was $102 \mu \mathrm{g} / \mathrm{ml}$, for $K$. pneumoniae was $308 \mu \mathrm{g} / \mathrm{ml}$ (Figure 6).

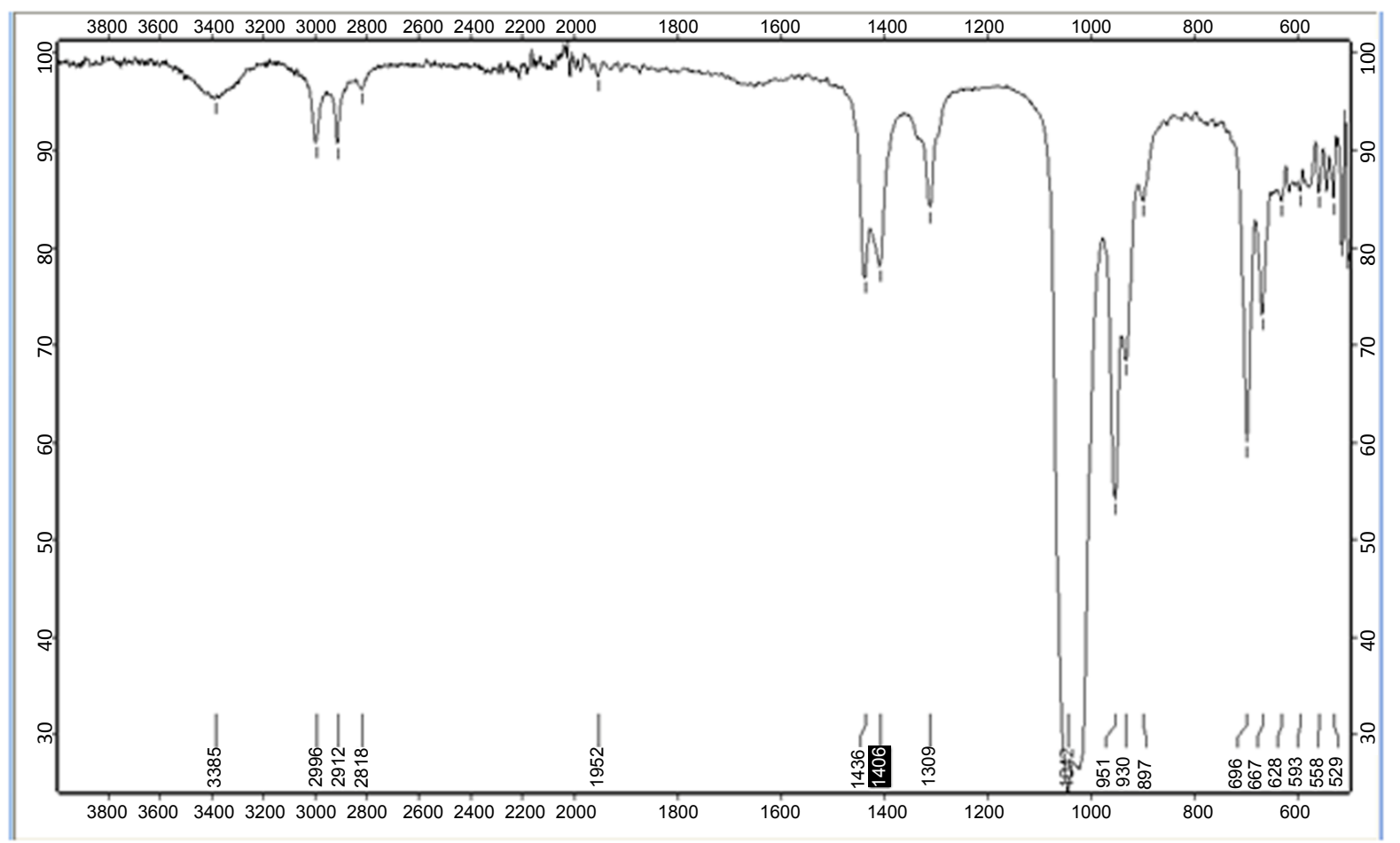

Figure 3: Representing image of FTIR analysis of AgNPs of endophytic fungus A. terreus. 
Citation: Rani R, Sharma D, Chaturvedi M, J P Yadav (2017) Green Synthesis, Characterization and Antibacterial Activity of Silver Nanoparticles of Endophytic Fungi Aspergillus terreus. J Nanomed Nanotechnol 8: 457. doi: 10.4172/2157-7439.1000457

Page 5 of 8

The zone of inhibition for MDR bacterial strains was ranging from $13.33 \pm 0.58$ to $15.33 \pm 0.58 \mathrm{~mm}$ (Table 2). P. aeruginosa (MDR) strain was reported to be most susceptible as showed highest zone of inhibition (15.33 $\pm 0.58 \mathrm{~mm})$. K. pneumoniae (MDR) strain was found to be least susceptible for synthesized AgNPs. MIC values observed for

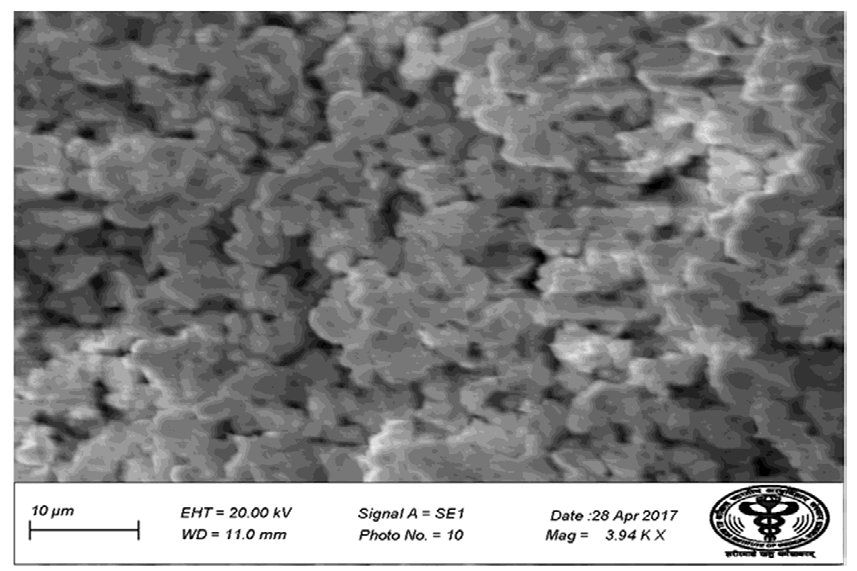

Figure 4: Representing image of scanning electron microscopy (SEM) of AgNPs of endophytic fungus $A$. terreus.

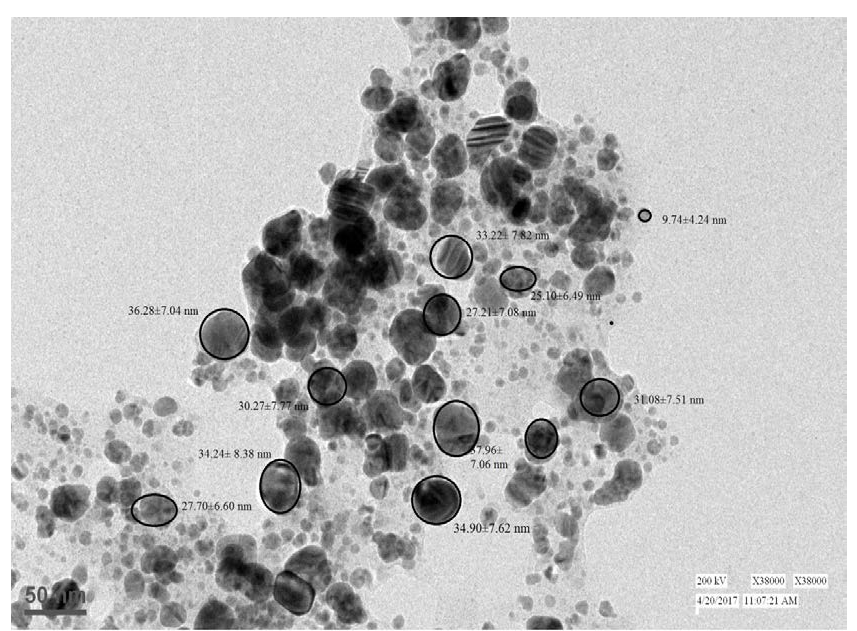

Figure 5: Representing image of transmission electron microscopy (TEM) of AgNPs of endophytic fungus $A$. terreus.
P. aeruginosa (MDR) was $34.2 \mu \mathrm{g} / \mathrm{ml}$, for $E$. coli was $102 \mu \mathrm{g} / \mathrm{ml}$, for $K$. pneumoniae was $308 \mu \mathrm{g} / \mathrm{ml}$ (Figure 6).

\section{Cell leakage analysis}

The amount of protein present in supernatant after treatment with AgNPs was quantified by using Bradford assay. In treated cells higher protein content was found than control. The protein leakage from the treated cell was reported in higher amount as compared to the control (Figure 7). Highest amount of extracellular protein after treatment with AgNPs was reported for $S$. typhi. Agarose gel electrophoresis showed the degraded band of nucleic acid after application of nanoparticles.

\section{Discussion}

After discovery of Penicillin, fungi were thoroughly investigated for presence of antimicrobial compounds. These compounds (secondary metabolites) are not only serves as antimicrobial agents but also provide a prototype structure for chemical synthesis of new antibacterial agents. There are several examples which indicated fungal metabolites serve as source directly or indirectly for production of drug molecules $[16,17]$. Many studies have been carried out to evaluate antibacterial activity of endophytic fungi and for isolation new antibacterial compounds $[11,18]$. But synthesis of AgNPs takes advantage of their small size and
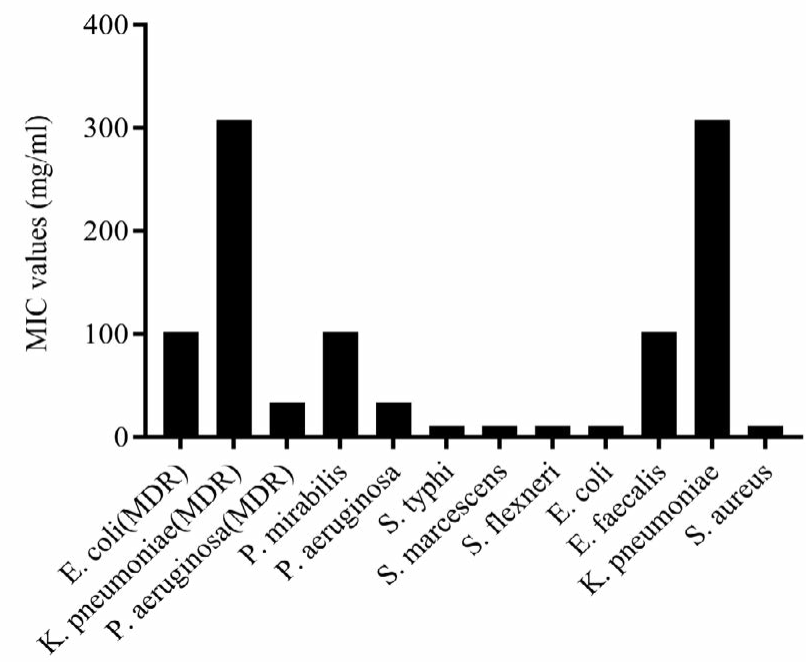

Figure 6: MIC of AgNPs against tested bacterial strains

\begin{tabular}{|l|c|c|c|}
\hline \multirow{2}{*}{ Bacterial strains } & \multicolumn{3}{c|}{ Synthesized silver nanoparticles } \\
\cline { 2 - 4 } & $\mathbf{1 0} \mathbf{~} \mathbf{g} / \mathbf{m l}$ & $\mathbf{2 0} \mathbf{~ m g} / \mathbf{m l}$ & $\mathbf{3 0 ~} \mathbf{~ g} / \mathbf{m l}$ \\
\hline K. coli (MDR) & $13.33 \pm 0.58$ & $13.67 \pm 0.58$ & $14.67 \pm 0.58$ \\
\hline P. aeruginosa (MDR) & $12.33 \pm 0.58$ & $12.67 \pm 0.58$ & $13.33 \pm 0.58$ \\
\hline P. mirabilis & $14.00 \pm 1.00$ & $15.00 \pm 1.00$ & $15.33 \pm 0.58$ \\
\hline P. aeruginosa & $11.67 \pm 0.58$ & $12.67 \pm 0.58$ & $13.33 \pm 0.58$ \\
\hline S. typhi & $12.67 \pm 0.58$ & $13.00 \pm 1.00$ & $13.67 \pm 0.58$ \\
\hline S. marcescens & $15.33 \pm 0.58$ & $15.67 \pm 0.58$ & $16.00 \pm 1.00$ \\
\hline S. flexneri & $12.67 \pm 0.58$ & $13.33 \pm 0.58$ & $14.67 \pm 0.58$ \\
\hline E. coli & $14.33 \pm 0.58$ & $14.33 \pm 0.58$ & $14.67 \pm 0.58$ \\
\hline E. faecalis & $14.67 \pm 0.58$ & $15.67 \pm 0.58$ & $15.67 \pm 0.58$ \\
\hline K. pneumoniae & $14.00 \pm 1.00$ & $15.00 \pm 1.00$ & $15.00 \pm 1.00$ \\
\hline S. aureus & $13.00 \pm 0.58$ & $13.33 \pm 1.00$ & $13.67 \pm 0.58$ \\
\hline & $14.67 \pm 0.58$ & $14.67 \pm 0.58$ & $15.33 \pm 0.58$ \\
\hline
\end{tabular}

\begin{tabular}{|c|c|c|c|}
\hline $\mathbf{4 0} \mathbf{~ m g / m l}$ & $\begin{array}{c}\text { Fungal } \\
\text { supernatant }\end{array}$ & $\begin{array}{c}\text { Silver } \\
\text { nitrate }\end{array}$ & $\begin{array}{c}\text { Standard } \\
(\mathbf{1 0} \mathbf{\mu g} / \text { disc })\end{array}$ \\
\hline $14.67 \pm 0.58$ & - & - & $22.33 \pm 0.58$ \\
\hline $13.33 \pm 0.58$ & - & - & $22.67 \pm 0.58$ \\
\hline $15.33 \pm 0.58$ & - & - & $21.00 \pm 1.00$ \\
\hline $14.67 \pm 0.58$ & - & - & $25.00 \pm 1.00$ \\
\hline $14.33 \pm 0.58$ & - & - & $23.00 \pm 1.00$ \\
\hline $16.67 \pm 0.58$ & - & - & $21.67 \pm 0.58$ \\
\hline $15.33 \pm 0.58$ & - & - & $22.33 \pm 0.58$ \\
\hline $14.67 \pm 0.58$ & - & - & $20.33 \pm 0.58$ \\
\hline $15.67 \pm 0.58$ & - & - & $25.33 \pm 0.58$ \\
\hline $15.00 \pm 1.00$ & - & - & $22.67 \pm 0.58$ \\
\hline $13.67 \pm 0.58$ & - & - & $24.67 \pm 0.58$ \\
\hline $15.67 \pm 0.58$ & - & - & $24.67 \pm 0.58$ \\
\hline
\end{tabular}

Table 2: Representing antibacterial activity of AgNPs at different concentrations, synthesized by using $A$. terreus against different reference and MDR bacterial strains. 


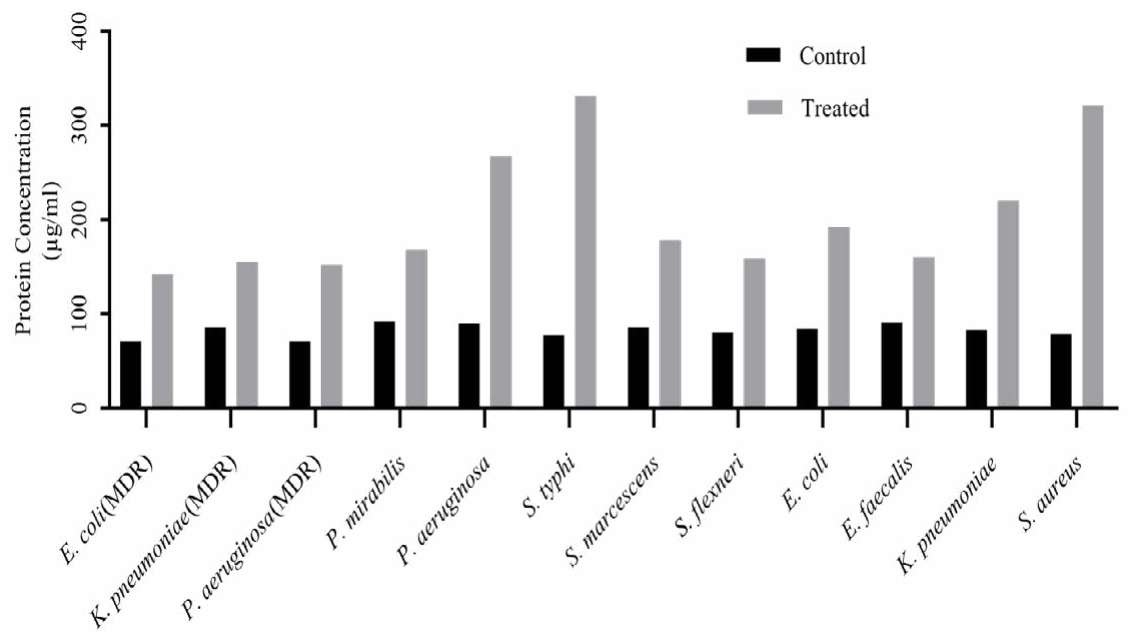

Figure 7: Graph representing estimation of protein leakage level in different bacterial strains after treatment with silver nanoparticles of $A$. terreus.

bioactivity of phytoconstituents. Endophytic fungi mediated synthesis of AgNPs provides an attractive and environmentally safe substitute to chemically and physically produced nanoparticles. In present study, the selected endophytic fungal strain i.e. A. terreus exhibited ability to synthesize AgNPs extracellularly. After synthesis, characterization of AgNPs is necessary to predict their physicochemical properties that could have a significant impact on their biological activity. Characterization techniques provides informations like size, shape, charge, solubility, aggregation, and function group involved in reduction and capping of nanoparticles $[19,20]$. Therefore, we used different characterization technique i.e. UV-Vis spectrophotometer, FTIR, SEM, and TEM for the analysis of synthesis of nanoparticles.

GC-MS analysis of A. terreus extract was carried out for identification of detailed phytoconstituents. It mainly showed the presence of carboxylic acids, esters, and steroids. They are reported to involve in the synthesis of nanoparticles [21,22]. It was previously reported that secondary metabolites present in endophytic fungi are responsible for synthesis and stabilization of AgNPs [8]. The present study hypothesizes that these metabolites might be responsible for the reduction of silver ions and formation of stable AgNPs.

First indication of nanoparticles production is the change in color of solution [23]. Generally, appearance of brown color indicates the production of AgNPs due to SPR phenomenon. Similar indications were also reported $[22,24]$. Many studies reported that spherical AgNPs show maximum absorbance between $400 \mathrm{~nm}$ to $450 \mathrm{~nm}$. The intensity and peak position due to SPR are related with size, morphology and dielectric properties of synthesized nanoparticles $[25,26]$. Slow decrease in absorbance after peak indicated the polydispersed behavior of AgNPs in solution [27,28].

The exact mechanism involved in nanoparticle synthesis may vary with biological extracts due to presence of different secondary metabolites and enzymes. Generally, phytochemicals responsible for synthesis of nanoparticles are terpenoids, flavones, ketones, aldehydes, amides, and carboxylic acids [3]. A. terreus showed the presence of tannins, flavanoids, phenols, diterpenes, alkaloids, glycosides and carbohydrates (data is not published yet). FTIR analysis of synthesized nanoparticles indicated the presence of many functional groups. Functional groups played important role in reduction and capping of silver ion to AgNPs $[29,30]$. Characteristic peaks showed the presence of alcohols and phenols which have been reported to assist reduction of silver ion to AgNPs [16]. Some studies also suggested the reduction and capping of silver ion is due to presence of NADHdependent reductases in endophytic fungal extracts [31,32]. SEM and TEM analysis were performed to know the morphology and size of synthesized nanoparticles. It was predicted to be round and oval shape of nanoparticles may be due to capping and stabilization of nanoparticles by secondary metabolites present in extract of $A$. terreus. TEM observations are in line with many earlier reports for AgNPs synthesized using various fungal extracts [33,34]. In present method, synthesis of silver nanoparticles was done extracellularly. Silver nanoparticles can be synthesized intracellularly but extract out the synthesized nanoparticles require cell lysis which is tedious and relatively costly [35].

In present study, we synthesized and characterized AgNPs from A. terreus and evaluate their antibacterial potential. Significant antibacterial activity of AgNPs was reported against all tested bacterial strains. Increase in zone of inhibition was reported with the increase in concentration of AgNPs. AgNPs inhibited the growth of reference and MDR bacterial strains effectively while, no zone of inhibition was reported for fungal filtrate and silver nitrate. So, the antibacterial activity of synthesized AgNPs may be attributed to their small size and high surface area which enable them to penetrate inside the bacterial cells.

There are various suggested mechanisms of action of AgNPs; AgNPs have ability to anchor to the bacterial cell wall, followed by penetration, thus change the permeability of cell membrane and results in bacterial cell death, produce free radicals when come in contact with bacterial cells [36], and they may release silver ion and these ion interact with thiol groups of many vital enzymes and inactivate them [37]. Many previous studies reported the antibacterial potential of endophytic fungi $A$. terreus $[11,18]$. Few studies also reported the synthesis of AgNPs from A. terreus and their bioactivity isolated from different host plants [38,39]. Abeer et al. [38] reported antimicrobial activity AgNPs synthesized from Aspergillus terreus KC462061 isolated from date palm against various fungal strains (Candida albicans, Aspergillus flavus, Aspergillus fumigates, and Aspergillus niger), and bacterial strain (Staphylococcus aureus) using the agar well diffusion method. Remarkable inhibitory in vitro antidermatophytic activity was found against Trichophyton rubrum, Epidermophyton floccosum and Trichophyton mentagrophytes of AgNPs synthesized using A. terreus isolated from host plant Rhizophora annamalayanna [39]. 
Citation: Rani R, Sharma D, Chaturvedi M, J P Yadav (2017) Green Synthesis, Characterization and Antibacterial Activity of Silver Nanoparticles of Endophytic Fungi Aspergillus terreus. J Nanomed Nanotechnol 8: 457. doi: 10.4172/2157-7439.1000457

Page 7 of 8

From literature it has been found that AgNPs have the capability to penetrate the bacterial cells thereby causing membrane dissociation. Protein and nucleic acid component thus released can be used as a marker to know cell integrity when compared with control cells i.e. without exposure to nanoparticles. Present study showed high amount of leaked protein and nucleic acids from the treated bacterial strains suggesting the irreversible loss of plasma membrane integrity. Increase in protein leakage and nucleic acid degradation analysis support our finding of disruption of bacterial membrane as reported in other studies also [40,41].

\section{Conclusion}

The present study indicates the synthesis of AgNPs using endophytic fungi $A$. terreus. Synthesized nanoparticles were characterized using various spectrophotometric techniques for their shape, size and functional group involved in bioreduction and stabilization of silver ions.

AgNPs showed significant antibacterial activity against reference and MDR strains. GC-MS analysis was carried out for detailed phytochemical analysis. Thus the biosynthesized AgNPs may be used as an alternative treatment therapy to control bacterial infections.

\section{Acknowledgement}

We would like to acknowledge AlIMS, New Delhi for providing SEM and TEM analysis facility. This research work was financially supported by a grant from DST [DST-INSPIRE, IF-140413] \& UGC-SAP [F.20/2012(SAP-II)].

\section{References}

1. Barrow JR, Lucero ME, Reyes-Vera I, Havstad KM (2008) Do symbiotic microbes have a role in regulating plant performance and response to stress? Commun Integr Biol 1: 69-73.

2. Cohen ML (1992) Epidemiology of drug resistance: implications for a postantimicrobial era. Sci 257: 1050-1055.

3. Prabhu S, Poulose EK (2012) Silver nanoparticles: mechanism of antimicrobial action, synthesis, medical applications, and toxicity effects. Int Nano Lett 2: $32-41$

4. Moreira LM, Carvalho EA, Bell MJ, Anjos V, Sant'Ana AC (2013) Thermo-optical properties of silver and gold nanofluids. J Therm Anal Calorim 114: 557-564.

5. Patra JK, Baek KH (2014) Green nanobiotechnology: factors affecting synthesis and characterization techniques. J Nanomater 2014: 1-12.

6. Krutyakov YA, Kudrinskiy AA, Olenin AY, Lisichkin GV (2008) Synthesis and properties of silver nanoparticles: advances and prospects. Russ Chem Rev 77: 233-257.

7. Dias MA, Lacerda IC, Pimentel PF, De Castro HF, Rosa CA (2002) Removal of heavy metals by an Aspergillus terreus strain immobilized in a polyurethane matrix. Lett Appl Microbiol 34: 46-50.

8. Singh D, Rathod V, Ninganagouda S, Herimath J, Kulkarni P (2013) Biosynthesis of silver nanoparticle by endophytic fungi Pencillium sp. isolated from Curcuma longa (turmeric) and its antibacterial activity against pathogenic gram negative bacteria. J Pharm Res 7: 448-453.

9. Narayanan KB, Sakthivel N (2010) Biological synthesis of metal nanoparticles by microbes. Adv Colloid Interface Sci 156: 1-13.

10. Schulz B, Wanke U, Draeger S, Aust HJ (1993) Endophytes from herbaceous plants and shrubs: effectiveness of surface sterilization methods. Mycol Res 97: $1447-1450$

11. Rani R, Sharma D, Chaturvedi M, Yadav JP (2017) Antibacterial activity of twenty different endophytic fungi isolated from Calotropis procera and time kill assay. Clin Microbiol 6: 1-6.

12. Sarker SD, Nahar L, Kumarasamy Y (2007) Microtitre plate-based antibacterial assay incorporating resazurin as an indicator of cell growth, and its application in the in vitro antibacterial screening of phytochemicals. Methods 42: 321-324.

13. Bradford MM (1976) A rapid and sensitive method for the quantitation of microgram quantities of protein utilizing the principle of protein-dye binding Anal Biochem 72: 248-254.

14. Okafor F, Janen A, Kukhtareva T, Edwards V, Curley M (2013) Green synthesis of silver nanoparticles, their characterization, application and antibacterial activity. Int J Environ Res Public Health 10: 5221-5238.

15. Priya MM, Selvi BK, Paul JA (2011) Green synthesis of silver nanoparticles from the leaf extracts of Euphorbia hirta and Nerium indicum. Dig J Nanomater Biostruct 6: 869-877.

16. Ghosh S, Patil S, Ahire M, Kitture R, Kale S, et al. (2012) Synthesis of silver nanoparticles using Dioscorea bulbifera tuber extract and evaluation of its synergistic potential in combination with antimicrobial agents. Int $J$ Nanomedicine 7: 483-496.

17. Singh T, Jyoti K, Patnaik A Singh A, Chauhan R et al. (2017) Biosynthesis, characterization and antibacterial activity of silver nanoparticles using an endophytic fungal supernatant of Raphanus sativus. J Genet Eng Biotechno 15: 31-39.

18. Yadav M, Yadav A, Kumar S, Yadav JP (2014) Evaluation of in vitro antimicrobial potential of endophytic fungi isolated from Eugenia jambolana Lam. Int J Pharm Pharm Sci 6: 208-211.

19. Gurunathan S, Han JW, Kim ES, Park JH, Kim JH (2015) Reduction of graphene oxide by resveratrol: a novel and simple biological method for the synthesis of an effective anticancer nanotherapeutic molecule. Int J Nanomedicine 10: 2951-2969.

20. Sapsford KE, Tyner KM, Dair BJ, Deschamps JR, Medintz IL (2011) Analyzing nanomaterial bioconjugates: a review of current and emerging purification and characterization techniques. Anal Chem 83: 4453-4488.

21. Abdel-Raouf N, Al-Enazi NM, Ibraheem IB (2013) Green biosynthesis of gold nanoparticles using Galaxaura elongata and characterization of their antibacterial activity. Arab J Chem 10: 3029-3039.

22. Perugu S, Nagati V, Bhanoori M (2016) Green synthesis of silver nanoparticles using leaf extract of medicinally potent plant Saraca indica. Appl Nanosci 6: 747-753.

23. Kalimuthu K, Babu RS, Venkataraman D, Bilal M, Gurunathan S (2008) Biosynthesis of silver nanocrystals by Bacillus licheniformis. Colloids Surf B Biointerfaces 65: 150-153.

24. Singh K, Panghal M, Kadyan S, Chaudhary U, Yadav JP (2014) Green silver nanoparticles of Phyllanthus amarus: as an antibacterial agent against multi drug resistant clinical isolates of Pseudomonas aeruginosa. J Nanobiotechnology 12: $40-48$.

25. Kelly KL, Coronado E, Zhao LL, Schatz GC (2003) The optical properties of metal nanoparticles: the influence of size, shape, and dielectric environment. ए Phys Chem B 107: 668-677.

26. Kilin DS, Prezhdo OV, Xia Y (2008) Shape-controlled synthesis of silver nanoparticles: Ab initio study of preferential surface coordination with citric acid. Chem Phys Lett 458: 113-116.

27. Ninganagouda S, Rathod V, Jyoti H, Singh D, Prema K (2013) Extracellular biosynthesis of silver nanoparticles using Aspergillus flavus and their antimicrobial activity against gram negative MDR strains. Int J Pharm Biol Sci 4: 222-229.

28. Sunkar S, Nachiyar CV (2012) Biogenesis of antibacterial silver nanoparticles using the endophytic bacterium Bacillus cereus isolated from Garcinia xanthochymus. Asian Pac J Trop Biomed 2: 953-959.

29. Niraimathi KL, Sudha V, Lavanya R, Brindha $P$ (2013) Biosynthesis of silver nanoparticles using Alternanthera sessilis (Linn.) extract and their antimicrobial, antioxidant activities. Colloids Surf B Biointerfaces 102: 288-291.

30. Prakash P, Gnanaprakasam P, Emmanuel R, Arokiyaraj S, Saravanan M (2013) Green synthesis of silver nanoparticles from leaf extract of Mimusops elengi, Linn. for enhanced antibacterial activity against multi drug resistant clinical isolates. Colloids Surf B Biointerfaces 108: 255-259.

31. Kathiresan K, Manivannan S, Nabeel MA, Dhivya B (2009) Studies on silve nanoparticles synthesized by a marine fungus, Penicillium fellutanum isolated from coastal mangrove sediment. Colloids Surf B Biointerfaces 71: 133-137.

32. Govender Y, Riddin TL, Gericke M, Whiteley CG (2010) On the enzymatic formation of platinum nanoparticles. IJ Nanopart Res 12: 261-271.

33. Li G, He D, Qian Y, Guan B, Gao S, et al. (2011) Fungus-mediated green 
Citation: Rani R, Sharma D, Chaturvedi M, J P Yadav (2017) Green Synthesis, Characterization and Antibacterial Activity of Silver Nanoparticles of Endophytic Fungi Aspergillus terreus. J Nanomed Nanotechnol 8: 457. doi: 10.4172/2157-7439.1000457

Page 8 of 8

synthesis of silver nanoparticles using Aspergillus terreus. Int J Mol Sci 13: 466-476

34. Devi LS, Bareh DA, Joshi SR (2014) Studies on biosynthesis of antimicrobia silver nanoparticles using endophytic fungi isolated from the ethno-medicinal plant Gloriosa superba L. Proc Natl Acad Sci, India Section B: Biol Sci 84: 1091-1099.

35. Kitching M, Ramani M, Marsili E (2015) Fungal biosynthesis of gold nanoparticles: mechanism and scale up. Microbiol Biotechnol 8: 904-917.

36. Tamboli DP, Lee DS (2013) Mechanistic antimicrobial approach of extracellularly synthesized silver nanoparticles against gram positive and gram negative bacteria. J Hazard Mater 260: 878-884.

37. Matsumura Y, Yoshikata K, Kunisaki SI, Tsuchido T (2003) Mode of bactericidal action of silver zeolite and its comparison with that of silver nitrate. Appl Environ Microbiol 69: 4278-4281.
38. Abeer RM, Aziz AE, Monira R, Alothmana AL, Saleh AE, et al. (2013) Green synthesis of silver nanoparticles using Aspergillus terreus (KC462061). Dig J Nanomat Biostruct 8: 1215-1225.

39. Kalaiselvam M (2013) Extracellular biosynthesis of silver nanoparticles by endophytic fungus Aspergillus terreus and its antidermatophytic activity. Int $\mathrm{J}$ Pharm Biol Arch 4: 481-487.

40. Henie EF, Zaiton H, Suhaila M (2009) Bacterial membrane disruption in food pathogens by Psidium guajava leaf extracts. Int Food Res 16: 297-311.

41. Arokiyaraj S, Vincent S, Saravanan M, Lee Y, Oh YK, et al. (2017) Green synthesis of silver nanoparticles using Rheum palmatum root extract and their antibacterial activity against Staphylococcus aureus and Pseudomonas aeruginosa. Artif Cells Nanomed Biotechnol 45: 372-379. 